\title{
REPORT OF THE WORKING GROUP ON STOCK IDENTITY*
}

\author{
Eduardo R. Secchi, Daniel Danilewicz, Paulo H. Ott, Renata Ramos, Marila Lazaro, Juliana Marigo and John Y. Wang
}

\section{Conservation concern of the franciscana}

The greatest threat to the franciscanas' survival is incidental captures in coastal gillnets throughout most of its range (Praderi et al., 1989, UNEP/CMS, 2000). Incidental captures reported from most of the areas along its distribution (e.g. Perez-Macri and Crespo, 1989; Praderi, 1997; Secchi et al., 1997; Di Beneditto et al., 1998; Kinas and Secchi, 1998; Ott, 1998; Kinas and Secchi, 1998; Bertozzi and Zerbini, 2000; Rosas, 2000) are apparently high. However, the full impact of these captures, even on a local basis, remains unclear mainly because the identity of stocks is not understood and because effort to estimate abundance has been low and limited to only one area (Secchi et al., 2001).

Because the threats to the species are likely to occur at different levels along its distribution, it is important to determine stock discreteness in order to guide conservation and management procedures on a local level. Despite some progress in understanding stock structure, the stocks upon which management should be applied still remain unknown. Parasite loads have been used to identify ecological stocks of franciscana in the southern portion of its distribution (southern Brazil, Uruguay and Argentina - see Aznar et al., 1995 and Andrade et al., 1997). Differences in the displacement loop (D-loop) region of the mtDNA between the two geographic forms of franciscana (proposed by Pinedo, 1991) were found, suggesting the existence of at least two genetic populations or management stocks (Secchi et al., 1998, Lazaro, 2000). Given the high monetary and ecological interests involved in the management of endangered species, it would seem prudent to base taxonomic decisions on broad and reliable information (Avise, 1989). Secchi (1999) emphasised that an adequate management of coastal gillnet fisheries could be reached by defining franciscana stocks using analyses of a variety of proxies and the phylogeographic concept of stock proposed by Dizon et al. (1992).

\section{Stock characterisation for conservation purposes}

In this report, we tentatively applied the stock concept of Dizon et al. to the franciscana with the aim of identifying units upon which short-term management actions (e.g. bycatch monitoring, set catch limits, monitoring of demographic trends) should take place promptly. Dizon et al., (1992) proposed a phylogeographic concept based on a hierarchical classification scheme to define stocks. Their scheme classifies populations into four categories: I - those having the highest probability of being evolutionary significant unit (ESUs) and are characterised by geographic separation and significant genetic distances;
II - populations are similarly characterised by significant genetic diversity, but with weak geographic partitioning; III - populations are the converse of category II (i.e., having little genetic differentiation between assemblages that are clearly separate and likely to be reproductively isolated); IV - assemblages have the lowest probability of being evolutionarily significant units and are characterised by extensive gene flow and no division by extrinsic barriers. In addition to phylogeographic designation, the information is also used in the classification, as indicated by single-letter abbreviations: distribution (a), population response (b), phenotypic data (c), and genotypic data (d). Evidence both for and against designating a population as a separate stock are included. For example, in the designation "Type III cd/a", information to the left of the solidus would be evidence for "lumping", to the right would be for "splitting". Missing letter abbreviations mean lack of reliable data (see Dizon et al., 1992 for further details).

\section{Applying Dizon et al.'s approach:}

The study case: Franciscana

\section{Taxonomy:}

Species: Pontoporia blainvillei

Intraspecific subdivision: geographic forms North and South (Pinedo, 1991) genetic populations North and South (Secchi et al., 1998)

\section{Provisional Proposed Management Subdivisions:}

i) Northern population: occurring to the North of Santa Catarina State, Brazil

i.1) animals from Espírito Santo to Northern Rio de Janeiro

i.2) animals from São Paulo to Santa Catarina

ii) Southern population: occurring to the South of Santa Catarina State

ii.1) animals from Rio Grande do Sul (southern Brazil) and Uruguay

ii.2) animals from Argentina

\section{Evidence:}

\section{a) Distribution}

\section{a.1) Geographic distribution and abundance data}

Information on distribution and abundance could be used as basic criteria for splitting stocks and, when additional data is lacking, disjunct populations might be considered different stock for conservative management purposes

\footnotetext{
* Information presented in this section was based mostly on a paper by Secchi, Danilewicz and Ott (in press) and is not to be used without previous consultation with the authors.
} 
(Dizon et al., 1992). The franciscana is endemic to the western South Atlantic Ocean, ranging from Itaúnas (18²5’S - 30² $\left.{ }^{\circ} \mathrm{W}\right)$, Espírito Santo, Brazil (Moreira and

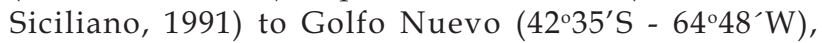
Península Valdés, Argentina (Crespo et al., 1998). A hypothesis of disjunct populations has been proposed based on two gaps observed in the distribution of the northern population (Siciliano and Santos, 1994; Siciliano et al., 2000). Information on the hiatus between Regência, Espírito Santo State $\left(19^{\circ} 40^{\prime} \mathrm{S}\right)$ and Atafona, northern Rio de Janeiro State $\left(21^{\circ} 37^{\prime} S\right)$ is incipient. However, continued effort in monitoring strandings and incidental captures confirms the second gap between Macaé, Rio de Janeiro State $\left(22^{\circ} 25^{\prime} S\right)$ and Ubatuba, northern São Paulo State (231's). Siciliano et al.'s (2000) findings suggest the existence of two isolated populations, one in northern Espírito Santo and the other in northern Rio de Janeiro State. According to the authors, the populations are associated with the runoffs of the Doce and Paraíba do Sul rivers because of the favourable conditions for feeding and protection against natural predators.

Although data on abundance exist only on a local basis (Secchi et al., 2001), empirical evidence suggests that the southern population is larger than the northern one. Captures of franciscanas are suspected, based on CPUE data, to be notoriously higher to the south (e.g. Crespo et al., 1986; Corcuera, 1994; Praderi, 1997; Secchi et al., 1997; Ott, 1998; Secchi and Ott, 2000), than to the north of Santa Catarina (e.g. Di Beneditto et al., 1998; Di Beneditto and Ramos, 2001; Bertozzi and Zerbini, 2000). This suspicion is supported by comparing data from systematic surveys of beached animals to the south (Pinedo and Polacheck, 1999) and north (Schiemegelow, 1990; Santos, 1999) of Santa Catarina.

\section{a.2) Contaminant loads}

Castello et al., (2000) found that female franciscanas from northern Argentina had a slightly higher mean concentration of PCBs (3.35ppm; sd = 1.95) than those from Rio Grande do Sul, southern Brazil (1.69ppm; sd = 1.61) while concentrations in males were similar. However, no statistical analyses were conducted by the authors. Borrel et al., (1997) analysed 17 females from Argentinean waters and found PCB concentrations to be similar to those found by O'Shea et al., (1980) in animals caught off Uruguay. DDTs and heavy metal studies are insufficient for comparative analyses. Although PCB contamination seems to indicate no stock division between southern Brazil, Uruguay and northern Argentina, temporal and methodological differences as well as the lack of data of the present studies limit the usefulness of contamination loads for stock definition.

\section{a.3) Parasite loads}

Andrade et al., (1997) stated that the distribution pattern of franciscana's gastrointestinal helminths was similar among individuals sampled in the Rio Grande do Sul and Uruguay. Franciscanas sampled in these areas were infected lightly by the acanthocephalan worm Polymorphus cetaceum whilst in Argentina, all the sampled franciscanas expereinced high levels of infection. The frequencies of dominant parasites were also different between animals from Rio Grande do Sul and Argentina. The trematode Hadwenius pontoporiae was present in $83 \%$ of the dolphins sampled in Rio Grande do Sul and P. cetaceum was found in $63 \%$ of the franciscana from Argentina. Aznar et al., (1995) compared the helminthfauna of franciscana between samples from Uruguay and Argentina and suggested some degree of stock segregation according to differences in dominance and infection levels by $P$. cetaceum, Anisakis simplex and H. pontoporiae. The studies of Aznar et al., (1994, 1995) and Andrade et al., (1997), showed that the parasite infection levels in franciscanas from Rio Grande do Sul and Uruguay were similar but considerably different from those sampled in Argentina. Some of the dominant parasites were also different between Argentina and the other areas. These findings suggest the existence of two ecologically distinct stocks: one comprising franciscanas from Rio Grande do Sul and Uruguay and the other being the animals of Argentinean waters. Because data on parasites infecting franciscana from Rio Grande do Sul (Andrade et al., 1997) are limited seasonally to spring, further studies are needed to strengthen the proposed division. Marigo et al. (2000), found significant difference in the occurrence of $H$. pontoporiae between the intestines of franciscanas from Paraná and São Paulo (prevalence $=68.4 \%$, this study) and those of franciscanas from Rio Grande do Sul (prevalence $=97.7 \%$, Andrade et al. 1997). In this context, the intestines of franciscanas from Rio de Janeiro could also indicate populational differences when compared with the population of São Paulo, Paraná and Rio Grande do Sul States. Therefore, it remains as a recommendation for further studies.

\section{a.4) Dietary differences}

Diet was more similar among individuals inhabiting adjacent areas of Rio Grande do Sul and Uruguay (see Pinedo, 1982; Pinedo et al., 1989; Ott, 1994; Bassoi, 1997) than between these two areas and Argentina (Perez et al., 1996; Perez et al., 2000; Rivero et al., 2000). The La Plata River is the only physical barrier between these supposed stocks and is probably the reason for the difference in feeding habits. Diet composition of individuals from the northern population is even more different (see Di Beneditto, 2000; Di Beneditto et al., 2000). Franciscanas from the southern population feed essentially on benthic species while franciscanas from the northern population (at least those from northern Rio de Janeiro) tend to forage on more pelagic species (see section on feeding habits in the Report of the Working Group on Biology and Ecology). These differences may reflect prey availability but also evolving behavioural adaptation to local niches.

\section{b) Population response}

Differences in reproductive timing represent an important line of evidence upon which stock structure can be based 
because of the implicit ecological or behavioural constraints that might limit gene flow between the two populations (Secchi, 1999). Southern and northern populations exhibit different reproductive strategies. According to Ramos et al., (2000), franciscanas in the northern distribution reproduce year round whilst the southern population has marked seasonal reproduction with the birth pulse spanning from approximately late austral spring to late summer (e.g. Kasuya and Brownell, 1979, Harrison et al., 1981, Pinedo et al., 1989; Corcuera, 1996, Danilewicz et al., 2000).

Although differences in deposition patterns of dentine and cementum in teeth may indicate clinal variation in water temperature, food availability and energetics, the growth layer groups (GLGs) for both the northern and southern populations seem to correspond to one annual cycle of deposition (Pinedo and Hohn, 2000, Ramos et al., 2000). Therefore, inter-populations comparisons of any age-related parameter are possible. Danilewicz et al., (2000) compared estimates on age at sexual maturity (ASM) of animals incidentally caught in gillnets in Rio Grande do Sul State with estimates from Uruguay (adapting data from Kasuya and Brownell, 1979) and from northern Argentina (Corcuera, 1996). Using the DeMaster method (DeMaster, 1978; 1984), the resulting ASM was 3.7 years $(95 \%$ CI $=3.0-4.4)$ in Rio Grande do Sul, 2.8 years $(95 \% \mathrm{CI}=2.5-3.1)$ in Uruguay and 4.5 years in Argentina. The ASM of females from Rio Grande do Sul was significantly higher than females from Uruguay $(\mathrm{t}=2.3 ; \mathrm{P}<0.01)$ but lower than those from Argentina. It should be noted that mature females only 2 years old were observed in Uruguay but not in Rio Grande do Sul. These young adult females contributed to the difference in the ASM from these two adjacent regions.

The findings of this comparative study are tentative so conclusions at the level of populations and ecosystem should be made cautiously until a more representative sample from Rio Grande do Sul and Argentina, and recent samples from Uruguay are available. Data from Uruguay were collected about 25 years ago (which corresponds to about three generations for franciscana), and the reproductive biology of the animals of the region may have changed substantially. It is tempting to explain the differences in ASM between the study regions as densitydependence. However, comparative studies on the life history of exploited marine mammal populations have failed to detect evidence of density-dependence or have produced contradictory results, even when sample sizes were very large and the history of exploitation well known (Chivers and Myrick, 1993). Nevertheless, the difference in ASM between the three areas requires further comparative investigations of the reproductive biology of the franciscana between southern Brazil and Argentina and encourages the collection of recent reproductive data from Uruguay. These differences may still be considered important in supporting the option of splitting the southern population into more than one management stock.

Little information on size/age at sexual maturity is available for most of the distribution of the northern population. The size at sexual maturity in males of the northern population was estimated between $112-116 \mathrm{~cm}$ for southern São Paulo/ northern Paraná States (Rosas, 2000) and $115 \mathrm{~cm}$ for northern Rio de Janeiro (Ramos et al., 2000). Females from São Paulo/ Paraná attain sexual maturity at $122 \mathrm{~cm}$ long, while the smallest sexually mature female from northern Rio de Janeiro was $130 \mathrm{~cm}$ long. The differences could be related to distinct somatic patterns between the regions. However, the sample size presented in Rosas (2000) was very small and any conclusions must be made cautiously.

Comparisons of age at sexual maturity between the southern and northern population are limited because of the relative small sample size available for the northern population and because of methodological differences in the analyses. Individuals from the southern population seem to be much larger at sexual maturity (see Kasuya and Brownell, 1979; Danilewicz and Secchi, 2000; Danilewicz et $a l ., 2000)$ than individuals from the northern population (see Ramos et al., 2000; Rosas, 2000).

\section{c) Phenotypic data}

The intra-specific variation in size, shape and colour in cetaceans may be as great as or greater than in terrestrial mammals. Analysis of morphological variation is helpful for understanding how much individuals or populations change their phenotype along time and space. It may also be useful for understanding micro-evolutionary processes within a species. Therefore, knowledge on the degree of morphological variation found along the distribution of the franciscana is an approach for determining stock structure. Based on osteological differences, Pinedo (1991) proposed two different forms of franciscana, one found to the north and the other to the south of Santa Catarina State, southern Brazil. This study showed that the animals from the north are smaller than animals from the south. The author also demonstrated that the two forms exhibited marked morphological differences that were not observed among individuals sampled from Rio Grande do Sul, Uruguay and Argentina. However, differences were observed between individuals from Argentina and those from Uruguay and Rio Grande do Sul. Some of the conclusions from Pinedo (1991), relevant to stock characterisation, include:

- no difference was observed in the measurement of the first GLG in the dentine and cementum among samples from Rio Grande do Sul and Uruguay;

- craniometrical analysis and measurements in the axial skeleton revealed the existence of two different geographic forms (a smaller form found to the north and a larger one to the south of Santa Catarina State).

Corroborating findings are presented by Ramos et al., (2000). They presented data on age and growth for individuals from the north and found asymptotic lengths (for both males and females) that were smaller than those found by Kasuya and Brownell (1979) for franciscanas from Uruguay. No differences were observed in the growth 
curves among individuals from Uruguay (recalculated from age and length data supplied by T. Kasuya to E.R.S.) and from Rio Grande do Sul (Walter et al., 1998). Although this information is closely related to the work of Pinedo (1991), it may be used as a supporting criterion for better defining a stock as a management unit.

Ramos et al. (2000) presented data on growth for the northern population and found that the growth parameters for individuals from São Paulo were smaller than the values obtained for individuals from northern Rio de Janeiro. The phenotypic difference between two geographic areas could be a reflection of distinct local adaptations. In addition, the asymptotic lengths presented by Rosas (2000) for São Paulo were also smaller than those found by Ramos et al. (2000) for northern Rio de Janeiro, corroborating this evidence. Differences in the somatic pattern represent important aspects supporting the hypothesis of distinct stocks with the northern population.

Inter-population analysis on franciscana's growth was conducted by Barreto et al. (2000). They used the Von Bertalanffy growth model to compare data on animals collected from Rio Grande do Sul with data from Paraná/ São Paulo. The asymptotic lengths of individuals from Rio Grande do Sul were significantly larger than individuals from Paraná/São Paulo ( $p<0.05$ - maximum likelihood test).

\section{d) Genotypic data}

Four hundred and eighty six base pairs of the mtDNA (68bp of proline tRNA and 418bp control region) of 10 franciscanas from each of two geographic form proposed by Pinedo (1991) were analysed (Secchi et al., 1998). Samples from Atafona (Rio de Janeiro State) and Rio Grande (Rio Grande do Sul State) provided direct genetic evidence for at least two genetic populations. The phylogeny of the haplotypes, two fixed substitutional differences (sites 202 and 356), network of haplotype interrelationships, and analysis of molecular variance all showed that the franciscana samples were separated into two distinct lineages.

Lázaro (2000a) and Hamilton et al. (2000) provided information on mtDNA analyses for franciscanas from Uruguay and Argentina. The two studies compared their results with those published by Secchi et al. (1998) and corroborated the hypothesis of at least two genetic populations of franciscana. Although data comparisons amongst the three studies do not support further division of franciscanas from Rio Grande do Sul, Uruguay and Claromecó (Argentina), a pairwise analysis of haplotype distances between different geographic locations showed increasing differentiation in the haplotype frequencies with increasing geographic distance, following an isolation-by-distance pattern (Lázaro, 2000b; 2001). Moreover, recent analysis showed that haplotypic frequencies of samples from Claramecó were significantly different from the rest of the southern population (Lázaro, 2001). This finding supports the proposed division of the southern population into different management stocks.

Zanelatto and Valsecchi (2000) presented preliminary results on the analysis of the mtDNA obtained from individuals collected in Paraná State, an intermediate region between Rio Grande and Atafona. Their results suggested that individuals from Paraná are more similar to those from Rio Grande do Sul than to those from Rio de Janeiro.

The results of these studies provide direct genetic support for population distinctions that are critical for conservation. Management-decision makers should recognise at least two (potentially more) genetically distinct populations.

\section{Classification}

The crude separation of franciscana into northern and southern genetic populations is unlikely to be sufficient for effective conservation of this species. Even after a distribution-wide genetic survey is complete, information on differences in population distribution, demography, morphology, incidental mortality and as many other criteria as possible must be integrated and considered when conservation strategies are designed.

The provisionally proposed stocks could be classified according to the hierarchical approach of Dizon et al., (1992). Data on genetics, morphology and growth, suspected abundance based on CPUE data, parasite loads, feeding habits/behaviour and population response indicate that the proposed northern and southern populations should be recognised as different stocks for management purposes. According to the phylogeographic approach these stocks should be classified as: Type II -/abcd meaning that all existing data support the existence of these two management stocks.

Regarding the proposed division of the southern population in two stocks, data on genetics, morphology and growth, suspected abundance based on CPUE did not support the splitting of franciscanas from Rio Grande do Sul/Uruguay and Argentina. However, data on mtDNA haplotypic frequencies, parasites load, feeding habits/behaviour and population response suggest splitting the southern population into two smaller stocks: one including animals from Rio Grande do Sul and Uruguay; and the other including franciscanas inhabiting Argentine waters. These stocks are, therefore, classified as Type IV acd/abd suggesting that the evidence for the splitting is weaker than for the southern and northern populations. The US Southwest Fishery Service Center recommends, as an averse-to-risk strategy, to consider a population as a different stock whenever any evidence suggest distinctiveness (e.g. genetic, morphology, population parameters or ecology) (see Taylor, 1994; 1997 and Dizon et al., 1997 p.11 and for supporting arguments). Therefore, recognizing this classification for applying management action on a local basis is recommended. Even though the De La Plata estuary would be the most appropriate ecological boundary for the two stocks, for management purposes, the most pragmatic separation between the stocks is the geopolitical border between Uruguay and Argentina. 


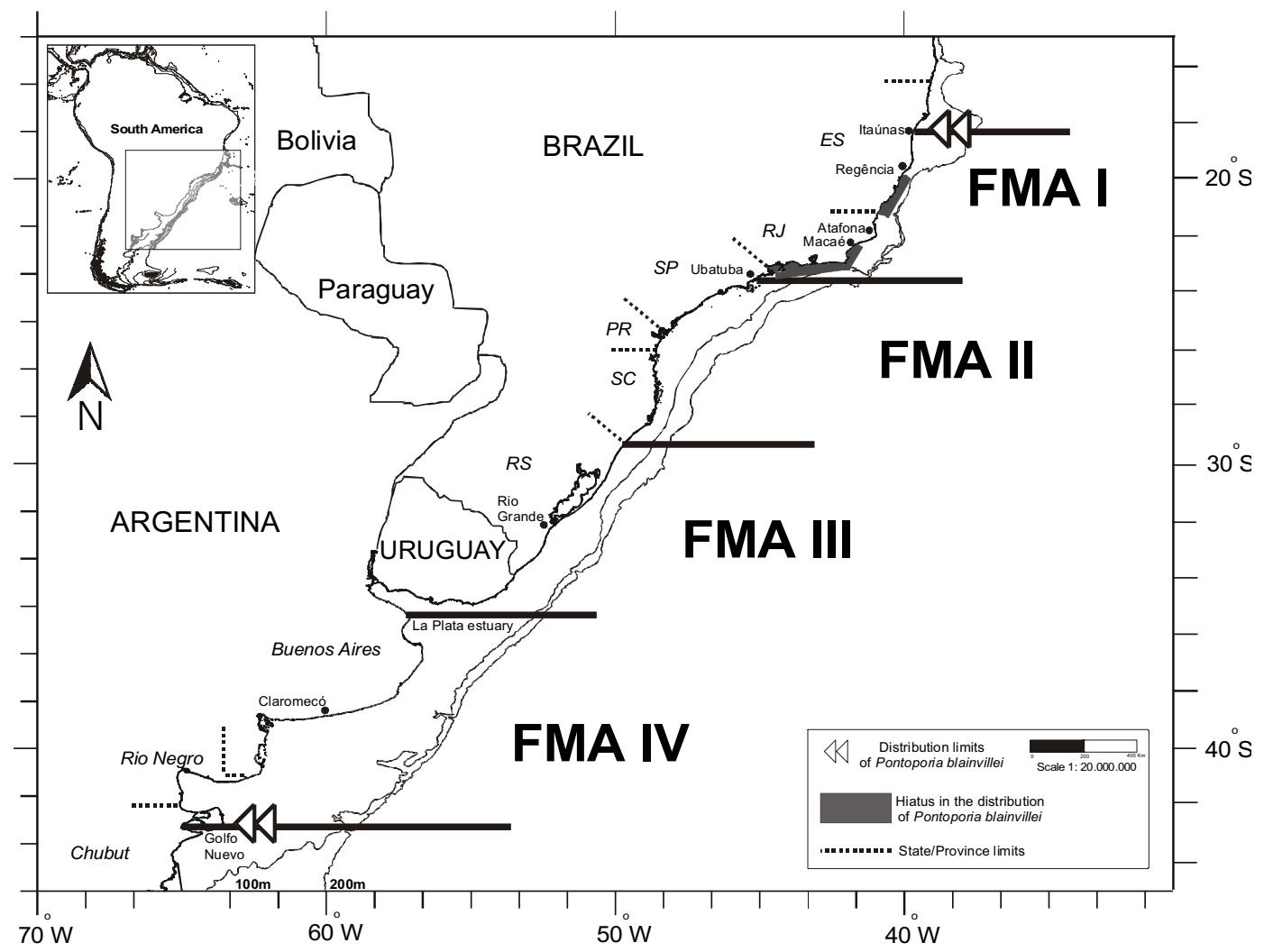

Figure 1. Proposed Franciscana Management Areas (FMAs).

For the proposed division of the northern population into two stocks, information on distribution, size at sexual maturity, growth and genetics, suggest the splitting of the northern population into two stocks of Type II -/abcd: one occurring from Espírito Santo to Rio de Janeiro states and the other from São Paulo to Santa Catarina states.

\section{Concluding Remarks}

Small-scale management is likely to be more effective and highly relevant in countries where resources are limited by the dominating economical situation to preventing the waste of limited resources in management actions that may have little chance to be effective. This is the case for the three countries where franciscana occurs. Data presented here suggest splitting each of the southern and the northern populations into two management stocks. We propose the establishment of four Franciscana Management Areas (FMAs): FMA I, includes the coastal waters of Espírito Santo and Rio de Janeiro; FMA II, covers São Paulo to Santa Catarina states; FMA III, is comprised of the coastal waters of Rio Grande do Sul and Uruguay; and FMA IV, represents the coastal waters of Argentina (including the provinces of Buenos Aires, Rio Negro and Chubut) (see Figure 1). However, these proposed divisions are not immutable. Intraspecific populations are dynamic and therefore, the proposed classification should be flexible and subject to change as new data become available. As stated by Dizon $e t$ al. (1992), they allow preliminary and conservative splitting of assemblages where data are lacking without the risk that these divisions become biological dogmas. Moreover, this hierarchical procedure for defining stocks permits managers and decisionmakers to direct limited resources to those stocks most likely in need of protection and also, it increases the chance of any management action to be effective.

\section{Recommendations}

For further improving our understanding on stock identity of franciscana, the following are recommended:

- Conduct temporally and methodologically synchronised comparative studies on parasite and contamination loads along the species range;

- Conduct genetic analyses for samples from areas between Atafona and Rio Grande and also from the northern and southern limits of the species range;

- Increase effort to estimate population parameters all along the species range;

- Reconsider the provisional stock subdivisions as new data are obtained.

\section{References}

Andrade, A.L.V., Pinedo, M.C. and Pereira Jr., J. (1997) Franciscanas from southern Brazil, Uruguay and North Argentina coasts: are one or more ecological stocks? Reports of the International Whaling Commission 47: 669-673. 
Avise, J.C. (1989) A role for molecular genetics in the recognition and conservation of endangered species. Trends in Ecology and Evolution 4: 279-81.

Aznar, F.J., Balbuena, J.A. and Raga, J.A. (1994) Helminth communities of Pontoporia blainvillei (Cetacea: Pontoporiidae) in Argentinean waters. Canadian Journal of Zoology 72: 702-706.

Aznar, F.J., Raga, J.A., Corcuera, J. and Monzón, F. (1995) Helminths as biological tags for franciscana (Pontoporia blainvillei) (Cetacea, Pontoporiidae) in Argentinean and Uruguayan waters. Mammalia 59: 427-435.

Barreto, A.S., Rosas, F.C.W. and Pinedo, M.C. (2000) Comparação do crescimento de duas população de Pontoporia blainvillei do litoral do Brasil através do modelo de Von Bertalanffy. Page 9 in Abstracts, IX Reunión de Trabajo de Espcialistas en Mamíferos Acuáticos de América del Sur. 30 October - 3 November. Buenos Aires.

Bassoi, M. (1997) Avaliação da dieta alimentar de toninha, Pontoporia blainvillei (Gervais \& D'Orbigny, 1844), capturadas acidentalmente na pesca costeira de emalhe no sul do Rio Grande do Sul. Bachelor Dissertation. Fundação Universidade do Rio Grande, Rio Grande. 68pp.

Bertozzi, C. and Zerbini, A.N. (2000) Capturas acidentais de franciscana, Pontoporia blainvillei, na pesca artesanal de Praia Grande, São Paulo, Brasil. Technical Paper WP22 presented to IV Workshop para a Coordenação da Pesquisa e Conservação da Franciscana, Pontoporia blainvillei, no Atlântico Sul Ocidental. 05-09 November, 2000. Porto Alegre.

Borrel, A., Pastor, T., Aguilar, A., Corcuera, J. and Monzón, F. (1997) Contaminación por DDT y PCBs en Pontoporia blainvillei de águas argentinas: variación com la edad y el sexo. Pages 62-69 in Pinedo, M.C. and Barreto, A.S. (Eds) Anais do $2^{\circ}$ Encontro sobre Coordenação de Pesquisa e Manejo da Franciscana. Ed. FURG, Rio Grande.

Castello, H.P., Junin, M., Rotman, F. and Sarti, G.C. (2000) Análisis de contaminantes organoclorados y metales pesados en franciscana, Pontoporia blainvillei, de Argentina y Brasil. Pages 46-50 in UNEP/ CMS (Eds) Report of the Third Workshop for Coordinated Research and Conservation of the Franciscana Dolphin (Pontoporia blainvillei) in the Southwestern Atlantic. UNEP/CMS, Bonn.

Chivers, S.J. and Myrick Jr., A.C. (1993) Comparison of age at sexual maturity and other reproductive parameters for two stocks of spotted dolphins, Stenella attenuata. Fishery Bulletin 91: 611-618.

Corcuera, J. (1994) Mortality of Pontoporia blainvillei in Northern Buenos Aires Province: the threat of small fishing camps. Pages 291-294 in Perrin, W.F, Donovan, G.P. and Barlow, J. (Eds) Gillnets and cetaceans. International Whaling Commission (special issue 15), Cambrige.

Corcuera, J. (1996) Edad de madurez sexual del delfin franciscana en el sur de la província de Buenos Aires - Argentina. Page 39 in Abstracts, VII Reunión de Trabajo de Especialistas en Mamíferos Acuáticos de América del Sur. 22-25 October. Viña del Mar.

Crespo, E.A., Perez-Macri, G. and Praderi, R. (1986) Estado atual de la población de franciscana (Pontoporia blainvillei) en las costas uruguayas. Pages 92-105 in Castello, H.P. (Ed.) Actas I Reunión de Trabajo de Especialistas en Mamíferos Acuáticos de América del Sur, Buenos Aires.

Crespo, E.A., Harris, G. and González, R. (1998) Group size and distributional range of the franciscana, Pontoporia blainvillei. Marine Mammal Science 14: 845-849.

Danilewicz, D.S. and Secchi, E.R. (2000) Reprodução em fêmeas de toninha, Pontoporia blainvillei, no Rio Grande do Sul. Technical Paper WP23 presented to the IV Workshop para a Coordenação da Pesquisa e Conservação da Franciscana, Pontoporia blainvillei, no Atlântico Sul Ocidental. 05-09 November, 2000. Porto Alegre.

Danilewicz, D.S., Secchi, E.R., Ott, P.H., and Moreno, I.M. (2000) Analysis of the age at sexual maturity and reproductive rates of franciscana (Pontoporia blainvillei) from Rio Grande do Sul, southern Brazil. Comunicações do Museu de Ciências e Tecnologia, PUCRS 13: 89-98.
Demaster, D.P. (1978) Calculation of the average age of sexual maturity in marine mammals. Journal of Fishery Research Board of Canada 35: 912-915.

Demaster, D.P. (1984) Review of techniques used to estimate the average age at attainment of sexual maturity in marine mammals. Pages 175-185 in Perrin, W.F., Brownell Jr., R.L. and Demaster, D.P. (Eds) Reproduction of Whales, Dolphins and Porpoises. Reports of the International Whaling Commission (Special Issue 6). Cambridge.

Di Beneditto, A.P. (2000) Ecologia alimentar de Pontoporia blainvillei $e$ Sotalia fluviatilis (Cetacea) na costa norte do Estado do Rio de Janeiro. Doctoral Thesis. Universidade Estadual do Norte Fluminense, Campos dos Goytacazes.173pp.

Di Beneditto, A.P.M., Ramos, R.M.A. and Lima, N.R.W. (1998) Fishing activity in northern Rio de Janeiro State (Brazil) and its relation with small cetaceans. Brazilian Archives Biology and Technology 41: 296-302.

Di Beneditto, A.P.M. and Ramos, R.M.A. (2000) Pontoporia blainvillei (Gervais \& D'Orbigny, 1844) in the northern Rio de Janeiro $\left(21^{\circ} 18^{\prime} \mathrm{S}-22^{\circ} 25^{\prime} \mathrm{S}\right)$, Brazil. Technical Paper WP11 presented to the IV Workshop para a Coordenação da Pesquisa e Conservação da Franciscana, Pontoporia blainvillei, no Atlântico Sul Ocidental. 05-09 November 2000. Porto Alegre.

Di Beneditto, A.P.M. and Ramos, R.M.A. (2001) Biologia e conservação de pequenos cetáceos no norte do estado do Rio de Janeiro. (Ciências Ambientais: UENF, Campos dos Goytacazes.)

Dizon, A.E., Lockyer, C., Perrin, W.F., Demaster, D.P. and Seisson, J. (1992) Rethinking the stock concept: a phylogeographic approach. Conservation Biology 6: 24-36.

Dizon, A.E., Chivers, S.J. and Perrin, W.F. (Eds) (1997) Molecular Genetics of Marine Mammals. Special Publication 3. Society for Marine Mammalogy. Allen Press, Inc., Lawrence.

Hamilton, H, Rosemberg, A., Corcuera, J., Monzon, F. and Brownell, R.L. (2000) Secuencias de la region control del ADN mitocondrial de la franciscana, Pontoporia blainvillei: comparacion entre poblaciones de Brasil y Argentina. Page 56 in Abstracts, IX Reunión de Trabalho de Especialistas en Mamíferos Acuáticos América del Sur. 30 October - 3 November, 2000. Buenos Aires, Argentina. 56pp. (Abstracts).

Kasuya, T. and Brownell, R.L. (1979) Age determination, reproduction and growth of franciscana dolphin, Pontoporia blainvillei. Scientific Reports of the Whales Research Institute 31: 45-67.

Kinas, P.G. and Secchi, E.R. (1998) Modelling truncated data to estimate incidental kills of franciscana, Pontoporia blainvillei, by gillnets. Reports of the International Whaling Commission 48: 533-536.

Lázaro, M. (2000a) Utilización de marcadores moleculares para el análisis de la variación genética y estructura poblacional de la franciscana (Pontoporia blainvillei). Pages 58-61 in UNEP/CMS (Eds). Report of the Third Workshop for Coordinated Research and Conservation of the Franciscana Dolphin (Pontoporia blainvillei) in the Southwestern Atlantic. UNEP/CMS, Bonn.

Lázaro, M. (2000b) Variacion genetica y estructura poblacional de la franciscana: aporte de un estudio basado en ejemplares de la costa uruguaya. Technical Paper WP12 presented to the IV Workshop para a Coordenação da Pesquisa e Conservação da Franciscana, Pontoporia blainvillei, no Atlântico Sul Ocidental. 05-09 November 2000. Porto Alegre.

Lazaro, M. (2001) Estructura genetica poblacional de la franciscana (Pontoporia blainvillei). Master Thesis. Universidad de la República Oriental del Uruguay, Montevideo. 93pp.

Marigo, J., Andrade, A.L.V. and Rosas, F.C.W. (2000) Intestinal parasites of Pontoporia blainvillei, from the states of Paraná and São Paulo, Brazil. Technical Paper WP4 presented to the IV Workshop para a Coordenação da Pesquisa e Conservação da Franciscana, Pontoporia blainvillei, no Atlântico Sul Ocidental. 05-09 November 2000. Porto Alegre. 
Moreira, L.M.P. and Siciliano, S. (1991) Northward extension range for Pontoporia blainvillei. Page 48 in Abstracts, IX Biennial Conference on the Biology of Marine Mammals. 05-09 December, Chicago.

O'Shea, T.J., Brownell Jr., R.L., Clark Jr., D.R., Walker, W.A., Cay, M.L. and Lamont, T.G. (1980) Organochlorine pollutants in small cetaceans from Pacific and South Atlantic Oceans, November 1968-June 1976. Pesticides Monitoring Journal 14: 35-46.

Ott. P.H. (1994) Estudo da Ecologia Alimentar de Pontoporia blainvillei (Gervais e D'Orbigny, 1844) (Cetacea, Pontoporiidae) no Litoral Norte do Rio Grande do Sul, Sul do Brasil. Bachelor Dissertation. Universidade Federal do Rio Grande do Sul, Porto Alegre, 69pp.

Ott, P.H. (1998) Análise das capturas acidentais de Pontoporia blainvillei (Gervais e D'Orbigny, 1844) (Cetacea, Pontoporiidae) nas comunidades pesqueiras do litoral norte do Rio Grande do Sul, Sul do Brasil. Master Thesis. PUC-RS, Porto Alegre. 121pp.

Perez, J.E., Gingarelli, M., Beilis, A. and Corcuera, J. (1996) Alimentación del delfín franciscana en el sur de la Provincia den Buenos Aires, Argentina. Page 91 in Abstracts, VII Reunión de Trabajo Especialistas en Mamíferos Acuáticos de América del Sur. 22-25 October, Viña del Mar.

Perez, J.E., Tamini, L.L., Chiaramonte, G. and Cappozzo, H.L. (2000) Un nuevo enfoque de la interacción entre el delfín franciscana (Pontoporia blainvillei) y la pesquería costera en el area de Puerto Quequén, Pcia. de Buenos Aires, Argentina. Page 100 in Abstracts, IX Reunión de Trabajo Especialistas en Mamíferos Acuáticos de América del Sur. 30 October - 3 November. Buenos Aires.

Perez-Macri, G. and Crespo, E.A. (1989) Survey of the franciscana, Pontoporia blainvillei, along the Argentine coast, with a preliminary evaluation of mortality in coastal fisheries. Pages 57-63 in Perrin, W.F., Brownell, R.L., Kaiya, Z. and Jiankang, L. (Eds) Biology and Conservation of the River Dolphins. Occas. pap. IUCN SSC 3. Gland.

Pinedo, M.C. (1982) Análise dos conteúdos estomacais de Pontoporia blainvillei (Gervais \& D'Orbigny, 1844) e Tursiops gephyreus (Lahille, 1908) (Cetacea, Platanistidae e Delphinidae) na zona estuarial e costeira de Rio Grande, R.S., Brasil. Master Thesis. Fundação Universidade do Rio Grande, Rio Grande. 95pp.

Pinedo, M.C. (1991) Development and variation of the franciscana Pontoporia blainvillei. Doctoral Thesis, University of California, Santa Cruz. 406pp.

Pinedo, M.C. and Polacheck, T. (1999) Trends in franciscana (Pontoporia blainvillei) stranding rates in Rio Grande do Sul, Southern Brazil (1979-1998). Journal of Cetacean Research and Management 1: 179-189.

Pinedo, M.C., Praderi, R. and Brownell Jr., R. (1989) Review of the biology and status of the franciscana Pontoporia blainvillei. Pages 46-51 in Perrin, W.F., Brownell, R.L., Kaiya, Z. and Jiankang, L. (Eds) Biology and Conservation of the River Dolphins. Occas. pap. IUCN SSC 3. Gland.

Pinedo, M.C. and Hohn, A. (2000) Growth layer patterns in teeth from the franciscana, Pontoporia blainvillei: developing a model for precision in age estimation. Marine Mammal Science 16: 1-27.

Praderi, R. (1997) Análisis comparativo de estadísticas de captura y mortalidad incidental de Pontoporia blainvillei em Uruguay durante 20 años. Pages 42-53 in M.C. Pinedo, and Barreto, A.S. (Eds) Anais do $2^{\circ}$ Encontro sobre Coordenação de Pesquisa e Manejo da Franciscana. Ed. FURG, Rio Grande.

Praderi, R., Pinedo, M.C. and Crespo, E.A. (1989) Conservation and management of Pontoporia blainvillei in Uruguay, Brazil and Argentina. Pages 52-56 in Perrin, W.F., Brownell, R.L., Kaiya, Z. and Jiankang, L. (Eds) Biology and Conservation of the River Dolphins. Occas. pap. IUCN SSC 3. Gland.

Ramos, R., Di Beneditto, A.P.M. and Lima, N.R.W. (2000) Growth parameters of Pontoporia blainvillei in northern Rio de Janeiro, Brazil. Aquatic Mammals 26.1: 65-75.
Ramos, R.M.A, Di Beneditto, A P., Siciliano, S., Santos, M.C., Zerbini, A.N., Bertozzi, C., Vicente, A., Zampirolli, E., Siqueira, F., De Vivo, M. and Lima, N.R.W. (2000) Informações sobre idade e crescimento de Pontoporia blainvillei no litoral sudeste do Brasil Technical Paper WP12 presented to the IV Workshop para a Coordenação da Pesquisa e Conservação da Franciscana, Pontoporia blainvillei, no Atlântico Sul Ocidental. 05-09 November 2000. Porto Alegre.

Rivero, L, Bastida, R. and Rodriguez, D. (2000) Ecologia trofica de la franciscana (Pontoporia blainvillei) en areas estuariales y marinas del norte de Argentina. Technical Paper WP21 presented to the IV Workshop para a Coordenação da Pesquisa e Conservação da Franciscana, Pontoporia blainvillei, no Atlântico Sul Ocidental. 05-09 November 2000. Porto Alegre.

Rosas, F.C.W. (2000) Interações com a pesca, mortalidade, idade, reprodução e crescimento de Sotalia guianensis e Pontoporia blainvillei (Cetacea, Delphinidae e Pontoporiidae) no litoral sul do Estado de São Paulo e litoral do Estado do Paraná, Brasil. Doctoral Thesis. Universidade do Paraná, Curitiba. 145pp.

Santos, M.C. de O. (1999) Novas informações sobre cetáceos no litoral sul de São Paulo e norte do Paraná com base em estudos sobre encalhes e na aplicação da técnica de foto-identificação individual de Sotalia fluviatilis (Cetacea, Delphinidae). Master Thesis. Universidade de São Paulo, São Paulo. 114pp.

Secchi, E.R. (1999) Taxa de crescimento potencial intrínseco de um estoque de franciscanas, Pontoporia blainvillei (Gervais \& D'Orbigny, 1844) (Cetacea, Pontoporiidae) sob o impacto da pesca costeira de emalhe. Master Thesis. Fundação Universidade Federal do Rio Grande, Rio Grande. 152pp.

Secchi, E.R. and Ott, P.H. (2000) A profundidade como um fator determinante da distribuição de toninhas, Pontoporia blainvillei, conforme indicado pelos índices de CPUE. Pages 55-57 in UNEP/CMS (Eds) Report of the Third Workshop for Coordinated Research and Conservation of the Franciscana Dolphin (Pontoporia blainvillei) in the Southwestern Atlantic. UNEP/CMS, Bonn.

Secchi, E.R., Zerbini, A.N., Bassoi, M., Dalla Rosa, L., Moller, L.M. and Roccha-Campos, C.C. (1997) Mortality of franciscanas, Pontoporia blainvillei, in coastal gillneting in southern Brazil: 1994-1995. Reports of the International Whaling Commission 47: 653-658.

Secchi, E.R., Wang, J.Y., Murray, B., Roccha-Campos, C.C. and White, B.N. (1998) Populational differences between franciscanas, Pontoporia blainvillei, from two geographical locations as indicated by sequences of mtDNA control region. Canadian Journal of Zoology 76: 1622-1627.

Secchi, E.R., Ott, P.H., Crespo, E.A., Kinas, P.G., Pedraza, S.N. and Bordino, P. (2001) A first estimate of franciscana (Pontoporia blainvillei) abundance off southern Brazil. Journal of Cetacean Research and Management 3: 95-100.

Secchi, E.R., Danilewicz, D., and Ott, P.H. (in press) Applying the phylogeographic concept to identify franciscana dolphin stocks: implications to meet management objectives. Journal of Cetacean Research and Management.

Siciliano, S. and Santos, M.C.O. (1994) Considerações sobre a distribuição da franciscana Pontoporia blainvillei no litoral sudeste do Brasil. Paper presented in II Encontro de Trabalho sobre a Coordenação de Pesquisa e Conservação da Franciscana, Florianópolis.

Siciliano, S., Di Beneditto, A.P., and Ramos, R.M.A. (2000) Populações isoladas do boto-amarelo Pontoporia blainvillei no sudeste do Brasil - considerações sobre o uso do hábitat e aspectos de conservação. Technical Paper WP16 presented to the IV Workshop para a Coordenação da Pesquisa e Conservação da Franciscana, Pontoporia blainvillei, no Atlântico Sul Ocidental. 05-09 November 2000. Porto Alegre.

Taylor, B. L. (1994) The potential effects of overlooking stock structure for management under the 1994 Amendments to the Marine 
Mammal Protection Act. Working Paper for the Workshop on Potential Biological Removal, held at the SWFSC, 27-29 June 1994.

Taylor, B.L. (1997) Defining "population" to meet management objectives for marine mammals. Pages 49-65 in Dizon, A.E., Chivers, S.J. and Perrin, W.F. (Eds) Molecular Genetics of Marine Mammals. Special Publication 3. Society for Marine Mammalogy. Allen Press, Inc., Lawrence.

UNEP/CMS. (2000) Report of the Third Workshop for Coordinated Research and Conservation of the Franciscana Dolphin (Pontoporia blainvillei) in the Southwestern Atlantic. UNEP/CMS, Bonn.
Walter, T., Kinas, P.G. and Secchi, E.R. (1998) Comparação entre o crescimento de toninha Pontoporia blainvillei ocorrente no extremo sul do Brasil e no Uruguai. Page 225 in Abstracts, VIII Reunião de Trabalhos de Especialistas em Mamíferos Aquáticos da América do Sul. 25-29 October, Olinda.

Zanelatto, R. and Valsecchi, E. (2000) Matrilineal society in the franciscana dolphin? A molecular clue. Technical Paper WP16 presented to the IV Workshop para a Coordenação da Pesquisa e Conservação da Franciscana, Pontoporia blainvillei, no Atlântico Sul Ocidental. 05-09 November 2000. Porto Alegre. 